УДК: 371

DOI: $10.15330 /$ esu. $1.92-96$
Тетлна Потапцук,

доктор педагогічних наук, професор,

ДВНЗ "Прикарпатський національний

університет імені Василя Стефаника"

(м. Івано-Франківськ)

Tetiana Potapchuk,

Doctor of pedagogical sciences, Professor,

Vasyl Stefanyk Precarpathian national university

(Ivano-Frankivsk, Ukraine)

tatvolod@ukr.net

\title{
ПРОФЕСІЙНА ПОЗИЦІЯ МАЙБУТНІХ УЧИТЕЛІВ ПОЧАТКОВИХ КЛАСІВ ЯК НАУКОВО-ПЕДАГОГГЧНА ПРОБЛЕМА
}

\section{PROFESSIONAL POSITION OF FUTURE PRIMARY SCHOOL TEACHERS AS A SCIENTIFIC AND PEDAGOGICAL PROBLEM}

У статті розглянуто прочес формування професійной позичій майбутніх учителів початкових класів, який є найбільи складним і наймени розробленим як у теоретичному, так $і$ в методичному аспектах, зважсаючи на його домінуючу роль, на наиу думку, у вихованні життево активних, гуманістично спрямованих громадян Украйни.

Однією з умов ефективного формування професійної позичій майбутніх учителів початкових класів є своєчасне виявлення домінуючих мотивів вибору професії, характеру відночення до обраної професії, можливостей та індивідуально-психологічних особливостей кожного з фахівиів, шо дас змогу вдосконалити професійну підготовку, надавати інформачію про професійну діяльність, про можливості застосування набутих знань, умінь, професійних компетентностей, розкриваючи нові можливості для реалізачій особистісного потенціалу особистості як майбутнього професіонала.

Ключові слова: позичія, професійна позичія, майбутні учителі початкових класів, особистісно-діяльнісна спрямованість.

The article considers the process of forming the professional position of future primary school teachers, which is the most complex and least developed in both theoretical and methodological aspects, given its dominant role, in our opinion, in the upbringing of vital, humanistic citizens of Ukraine.

One of the conditions for the effective formation of the professional position of future primary school teachers is timely identification of the dominant motives for choosing a profession, the nature of the attitude to the chosen profession, the opportunities and individual-psychological characteristics of each of the specialists, which allows to improve vocational training, provide information about the profession, application of acquired knowledge, skills, professional competences, opening new opportunities for realizing the personal potential of the individual as a future it professional.

According to the majority of scientists, the main tasks of training future specialists should be purposeful preparation for informational, moral and socio-psychological impact on the individual. The authors determine the direction of effective training of future specialists, namely: personal-activity orientation of content, methods, organization of pedagogical training; conceptual unity of content, forms and methods of learning; problem-methodological nature of training; cross-curricular links in the teaching of psychological and pedagogical disciplines; individualization and differentiation of professional activity.

According to the majority of scientists, the main tasks of training future specialists should be purposeful preparation for informational, moral and socio-psychological impact on the individual. The position of a future elementary school teacher is a system of those intellectual, volitional and emotional-evaluative relations to the world, pedagogical reality and pedagogical 
activity that are the source of his activity. The authors quite rightly, emphasize the orientation of the future teacher's position, his activity. On the one hand, according to scientists, it (pedagogical position) is determined by the demands, expectations and opportunities presented and provided by the teacher's society.

Key words: position, professional position, future elementary school teachers, personality and activity orientation.

Постановка проблеми у загальному вигляді та ї̈ зв'язок із важливими науковими чи практичними завданнями. Основними завданнями підготовки майбутніх фахівців, на думку більшості науковців, має стати цілеспрямована підготовка до інформаційного, морального і соціально-психологічного впливу на особистість. Автори визначають напрям ефективної підготовки майбутніх фахівців, а саме: особистісно-діяльнісна спрямованість змісту, методики, організації педагогічної підготовки; концептуальна єдність змісту, форм і методів навчання; проблемно-методологічний характер навчання; міжпредметні зв'язки в процесі викладання психолого-педагогічних дисциплін; індивідуалізація і диференціація професійної діяльності [1].

Мета статті - визначити зміст понять "позиція", “професійна позиція майбутнього вчителя" у наукових дослідженнях.

Аналіз останніх досліджень і публікацій в яких започатковано розв'язання порушеної проблеми i на які спирається автор. Проблемі професійної позиції присвячений ряд вітчизняних і зарубіжних наукових праць, у яких це явище розглядається, як інтегративний феномен, шо $\epsilon$ характеристикою особистості в цілому (К. Альбуханова - Славська, Л. Анциферова, О. Асмолов, Б. Братусь і ін.); як спосіб реалізації базових цінностей особистості (В. Слободчиков, А. Григор'єва і ін.); як центральний компонент освіченості особистості (О. Коршунов, О. Лебедєв, В. Монтатов і ін.); як джерело активності особистості вчителя (I. Ісаєв, О. Міщенко, В. Сластьонін, С. Шиянов і ін.); як результат взаємопроникнень соціальних, професійних та індивідуальних типових рис особистості (Д. Майєрс, I. Кон, О. Газман, А. Петровський та інші), як система ставлень особистості до професії (А. Маркова, М. Боритко, С. Вершловський, М. Сергєєв і ін.) [2].

Виклад основного матеріалу дослідження 3 повним обгрунтуванням одержаних наукових результатів. Вивчаючи феномен професійної позиції майбутнього вчителя початкових класів, нами здійснено аналіз досліджуваного явища.

У довідкових джерелах категорія "позиція" (від лат. positio - положення) - це положення, постава; розташування чого-небудь; точка зору, ставлення до чогонебудь, що визначає характер поведінки, дії; поведінка, характер дій, що зумовлені цією точкою зору, цим ставленням [3, с. 757]. За психологічним словником "позиція - це стійка система відносин людини до певних сторін дійсності, що проявляється у відповідній поведінці і вчинках. Позиція - утворення, що розвивається; іiі зрілість характеризується несуперечністю і відносною стабільністю" [4, с. 414].

Так, у філософії ця проблема розглядається на загальнометодологічному рівні у розрізі дослідження активної життєвої позиції людини в цілому як форма світоглядного підходу до їі трактування і конкретизується у працях багатьох відомих мислителів у контексті становлення життєвої позиції як основи самовираження (Сократ, Піфагор, Конфуцій і ін.). Позиція у філософії, як основа професійної позиції зокрема, виступає в якості позиції як точки зору, твердження, переконання, ролі; позиції людини, яка виховує і навчає; позиції як способу прояву і самоздійснення 
особистості; позиції як світогляду, сповненого духовно - моральним, ціннісним, етичним, праксіологічним та художньо - естетичним змістом [5, с. 76-120].

У працях психологів, зокрема Р. Немова, це поняття означає офіційне положення людини у тій чи іншій підсистемі стосунків [6 немов 4, 538]. Конструктивним у площині окресленої проблеми нам видається твердження В. М'ясищева, згідно з яким позиція відображає домінантні й вибіркові ставлення людини до того, що є для неї суттєвим [7].

Особливо важливим $є$ феномен професійної позиції вчителя у педагогіці, де він тісно пов'язаний з суспільно - політичними змінами історичного процесу, які зумовлювали динаміку провідних особистісних якостей і суб'єктних властивостей вчителя. Про це свідчить детальний аналіз історико - педагогічного аспекту вивчення педагогічної позиції.

У первісному суспільстві дорослі займали позицію вихователів 3 метою передачі життєвого досвіду молодшому поколінню. У рабовласницькому суспільстві, коли з'явились перші вчителі, зокрема, в державах Давнього Сходу (у Вавилоні, Сгипті, Сирії), функції педагога виконували жреці, у більшості випадків виступаючи з позиції вчителя - мудреця, духовного наставника. 3 іншого боку, у Давній Греції, вчителі вважали за необхідне формування не лише розумових, а й творчих і мистецьких здібностей, і виступали 3 позицій і вихователя, $\mathrm{i}$ „скульптора, майстра, який навчав дітей гімнастиці, як одному з видів спортивного мистецтва, прагнучи зробити їх фізично красивими і досконалими (Афіни), а також, - 3 позицій суворого і вимогливого тренера, виконуючи функцію підготовки до суспільного життя мужніх, дисциплінованих, загартованих, грамотних i фізично довершених воїнів (Спарта). У Древньому Римі педагог займав не лише позицію вчителя наставника, а й позицію політика, дипломата, інформатора, знавця, порадника i керівника, оскільки римські вчителі були державними чиновниками і мали знати багато наук. У Древньому Китаї вчитель також мав бути різносторонньою, обізнаною людиною, в усьому керуючись правилами гарного тону i займаючи етичну позицію. У часи Київськоїй Русі функції вчителя реалізовувались 3 позицій батька та володаря [8].

Отже, у давні часи позиція вчителя мала лише певний типологічний контекст $\mathbf{i}$ координувала функції вчителя, проте, зі зростаючими потребами суспільства, у професії вчителя вона поступово перетворюється і доповнюється новим змістом. Так, у середні віки, при феодально - кріпосницькому устрої позиція педагога набуває особливого історичного колориту: вчитель мав займати, перш за все, позицію духівника, знати релігії, богословські твори, вправно володіти церковним співом, а 3 іншого боку, - культурно - світоглядну і лицарську позиції: мав вивчати окремі науки, володіти навиками верхової їди та вміти користуватися зброєю. Ці знання, уміння і навики були потрібні середньовічному вчителю для навчання двох пануючих суспільних груп того періоду: світських дворян, або лицарів, і духівництва [9].

В Епоху Відродження професія вчителя стала більш розповсюдженою через появу в середині феодального суспільства буржуазії і паростків капіталістичного способу виробництва. Наставників - церковнослужителів поступово витіснили вчителі зі світською позицією, серед яких помітно виділились педагоги - гуманісти (Т. Кампанелла і ін.); письменники - представники педагогічної думки (Т. Мор, Ф. Рабле, Е. Роттердамський, М. Монтень, Ф. Дістервег, Й. Гербарт, М. Монтессорі, С. Френе і ін.) [10]. 
3 цього часу гуманність у позиції майбутнього вчителя початкових класів посідає найважливіше місце. Таким чином, на різних етапах розвитку і становлення педагогічної думки позиція вчителя розглядалась у розрізі основоположних рис $\mathrm{i}$ якостей педагога кожної конкретної епохи, зумовлених історичним процесом. В період Середньовіччя вчитель пропагував позиції людського буття, а в епоху Реформації центральне місце приділялося гносеології. Але проблема формування професійної позиції майбутнього вчителя початкових класів все ще не виступала як самостійна, так само і зміст поняття лишався нерозкритим [9].

Позиція майбутнього вчителя початкових класів - це система тих інтелектуальних, вольових і емоційно-оцінних стосунків до світу, педагогічної дійсності і педагогічної діяльності, які є джерелом його активності. Автори цілком слушно, наголошують на спрямованості позиції майбутнього вчителя, його активності. 3 одного боку, як стверджують науковці, вона (педагогічна позиція) визначається вимогами, очікуваннями i можливостями, що пред'являються i надаються суспільством учителю. А з іншого, - необхідно враховувати дію внутрішніх джерел активності особистості педагога - його нахили, переживання, мотиви, цілі, ціннісні орієнтації, ідеали - тобто все те, що визначає світогляд [11].

Висновки та перспективи подальших досліджень. Таким чином, у позиції майбутнього вчителя початкових класів проявляються його особистість, характер соціальної орієнтації, тип грамадянської поведінки і діяльності (громадянська позиція). А відтак, позицію майбутнього вчителя початкових класів можна трактувати як сукупність і взаємодію двох ії складових: соціальної і професійної.

Отже, враховуючи погляди багатьох науковців, можемо стверджувати, що професійна підготовка й особистісна активність майбутнього фахівця $\epsilon$ визначальним компонентом у формуванні професійної позиції майбутніх вчителів початкових класів. Адже педагогічні умови $є$ лише зовнішнім фактором впливу на майбутнього фахівця, а сама позиція особистості, враховуючи сукупність мотивів, інтересів, бажань - це вже усвідомлене цілеспрямоване прагнення з потребою у професійному зростанні, a, отже, і розвитку необхідних професійно-важливих якостей згідно обраної професії.

Подальшого вивчення потребують такі аспекти проблеми: розробка індивідуальних моделей формування професійної позиції майбутніх учителів початкових класів у процесі виховної роботи з молодшими школярами.

Література

1. Корольчук, М. С., Крайнюк В. М. Теорія і практика професійного відбору. К.: Ніка-Центр, $2006.536 \mathrm{c}$

2. Щербина Д. В. Формування активної комунікативної позиції учнів основної школи засобами імітаційно-ігрового навчання: автореф. дис.. ... канд. пед. наук 13.00.09 - теорія навчання. Кривий Ріг. 2009. 24 с.

3. Новий тлумачний словник української мови [уклад. В. Яременко, О. Сліпушко]. 2-ге вид., виправлене. Т. 3. К.: Аконіт, 2008. 862 с.

4. Словарь практического психолога. Сост. С. Ю. Головин. Минск : Харвест, 1998. 800 с.

5. Мясищев В. Н. Основные проблемы и современное состояние отношений человека. М.: Изд-во МГУ, 1980. Т. 2. С. $110-125$.

6. Немов Р. С. Психология: учеб. для студ. высш. учеб. заведений: в 3 кн. Кн. 3 . Экспериментальная педагогическая психология и психодиагностика. М. : Просвещение : ВЛАДОС, $1995.512 \mathrm{c}$.

7. Мясищев В. Н. Психология отношений: избр. психол. тр. М. : Изд-во Ин-т практ. психол., $1995.335 \mathrm{c}$

8. Левківський М.В. Історія педагогіки. Житомир, 2002. 200 с. 
9. Літовка О. П. Професійна позиція майбутнього вчителя: андрагогічний аспект. Bicн. Черкас. yн-my: Педагогічні науки. 2013. № 10 (263). С. $72-77$.

10. Пискунов А.И. Хрестоматия по истории зарубежной педагогики. М.: Просвещение, 1981. 864 c.

11. Пріма Д. Професійна позиція як науковий феномен. Науковий вісник МНУ імені В. О. Сухомлинського. Педагогічні науки. № 2 (65), травень, 2019. С. 233-236.

\section{References}

1. Korolchuk, MS, Kraineuk VM The theory and practice of professional selection. $\mathrm{K} . \therefore$ Nika-Center, $2006.536 \mathrm{p}$.

2. Shcherbina DV Formation of active communicative position of elementary school students by means of imitation-game training: author. dissertation ... ... Cand. ped. Sciences 13.00.09 - Theory of learning. Krivoy Rog. 2009. 24 p.

3. A New Interpretative Dictionary of the Ukrainian Language [comp. V. Yaremenko, O. Slipushko]. 2nd ed., Correction. Vol. 3. K.: Aconite, 2008. 862 p.

4. Dictionary of practical psychologist. Comp. S. Y. Golovin. Minsk: Harvest, 1998. 800 p.

5. VN Myasishchev Main problems and the current state of human relations. M $\therefore$ Moscow State University Publishing House, 1980. T. 2. P. 110-125.

6. Nemov RS Psychology: textbook. for students. higher training. Institution: in 3 books. Book. 3. Experimental pedagogical psychology and psychodiagnostics. M.: Enlightenment: VLADOS, 1995 $512 \mathrm{p}$.

7. VN Myasishchev, Psychology of Relations: Selected. psych. tr. M.: Publisher In-t Pract. Psych., 1995. $335 \mathrm{p}$.

8. Levkovsky MV History of pedagogy. Zhytomyr, 2002. 200 p.

9. Litovka OP Professional position of the future teacher: the andragogical aspect. Visn. Cherkasy. Universities: Pedagogical sciences. 2013. No. 10 (263). Pp. $72-77$.

10. Piskunov AI Readings on the history of foreign pedagogy. M .: Enlightenment, 1981. 864 p.

11. Prima D. Professional position as a scientific phenomenon. Scientific Bulletin of MNU. O. Sukhomlinsky. Pedagogical Sciences. No. 2 (65), May 2019. pp. 233-236.

Одержано статтю: 3.09 .2019

Прийнято до друку: 27.09.2019

УДК $37: 378.3$

DOI: $10.15330 /$ esu.1.96-102

\section{Юлія Халемендик,}

кандидат педагогічних наук,

Запорізыкий національний університет

(м. Запоріжжя, Україна)

Yuliia Khalemendyk,

Candidate of pedagogical sciences $(\mathrm{PhD})$,

Zaporizhzhia national university

(Zaporizhzhia, Ukraine)

halemendyk@gmail.com

\section{ВИХОВАННЯ СТУДЕНТСЬКОЇ МОЛОДІ ПІД ЧАС ВИВЧЕННЯ АНГЛИЙСЬКОї МОВИ В УНІВЕРСИТЕТАХ}

\section{THE EDUCATION OF STUDENT YOUTH WHILE STUDYING ENGLISH AT UNIVERSITIES}

У статті висвітлено актуальність виховання студентів у процесі вивчения англійської мови в університетах. Обірунтовано, ио виховна робота зі студентами на заняттях $з$ англійської мови є значуцою для трансляції історичного, культурного та духовного досвіду англомовних країн. Виокремлено проблеми визначення змісту виховання студентської молоді у вищий иколі: відповідність завдань виховання студентів реформуванню украйнського суспільства, невизначеність меж повноважень $i$ ролі викладача $i$ студентськой молоді у виховній роботі, відсутність вимог до студентів як особистостей $i$ 